\title{
The Impact of Banks Loan to SMEs on Manufacturing Output in Nigeria
}

\author{
*NWOSA Philip Ifeakachukwu, OSENI Isiaq Olasunkanmi \\ Bells University of Technology, Otta, Ogun State, Nigeria \\ *nwosaphilip@yahoo.com
}

\begin{abstract}
This study examines the impact of banks loan to SMEs on manufacturing output in Nigeria for the period spanning 1992 to 2010. The study employed an error correction modeling technique and observed that banks loan to the SME sector had insignificant impact on manufacturing output both in the long and short run. Based on the findings, the study recommended the need for greater deliberation and conscious effort by the government in ensuring that loans are given to ultimate users. There is also the need for moderation of collaterals and interest rate attached to banks loan to SMEs, to make it more attractive to stakeholders in the SMEs sector.
\end{abstract}

Key words: SMEs, Manufacturing output, Nigeria

\section{Introduction}

In recent years, the contributions of the Small and Medium Enterprise (SME) sector to output growth and employment generation in United States and some Asian countries has renewed the focus of economic planners and policymakers in Nigeria on the importance of the SME sector in aiding industrial growth and reducing the level of unemployment rate in the country. This has led to the initiation of programs capable of enhancing the performance of the SMEs sector in Nigeria. Among the programs and institutions established in the past for the growth of the sector include: the Small Scale Industries Credit Scheme (SSIC); Industrial Development Centers (IDCs); National Directorate of Employment (NDE); Working for Yourself program (WFYP); The Nigerian Industrial Development Bank (NIDB) and the National Economic Reconstruction Fund (NERFUND). Also, in 2001 the Nigeria Bankers' Committee initiated the Small and Medium Industries Equity Investment Scheme (SMIEIS). This scheme requires banks to set aside annually 10 per cent of their profit before tax for financing and promoting the Small and Medium Enterprises in the country. The abovementioned initiated programs were geared at increasing the amount of credit advanced to the SME sector in order to spur the performance of the sector. In addition and according to the Central Bank of Nigeria (CBN) of Nigeria Statistical bulletin, commercial banks have been advancing loans to the SMEs sector since 1992. However, questions on the extent to which the banks loans to the SMEs sector have impacted on the manufacturing sector of the Nigerian economy have remained noticeably silent in the literature. Although various articles have been written on the SME sector in the dailies and journals (see Aremu and Adeyemi, 2011; Hassan and Olaniran, 2011; Asikhia, 2009; Ogujiuba, et al., 2004; Sanusi, 2003), these studies failed to empirically evaluate the impact of bank loan to SME sector on manufacturing output in Nigeria, this is the main focus of this study. In addition, as the country prepares to join the top 20 economies by 2020 through the achievement of an expected annual economic growth rate between 13-15 per cent, it is pertinent to examine this issue as a basis for evaluating the performance of the SME sector. The rest of the paper is structured as follows. In addition to the introduction, section two presents a review of related studies while section three discusses the methodology on which this study is based. Section four presents the analysis of empirical results while section five discussed summary and policy recommendations.

\section{Literature Review}

Given the prominent role played by the SMEs sector in nation building, plethora of studies have assessed the performance of the sector in the light of the various policies and programs adopted to stimulate the growth of the sector. Aremu and Adeyemi (2011) examined the role of small and medium scale enterprises as a survival strategy for employment generation in Nigeria. The study observed that the SME sector is the main driving force behind job creation, poverty reduction, wealth creation, income distribution and reduction in income 
disparities in Nigeria and that most of the government interventions failed to create a much needed transformation due to poor coordination and monitoring and policy inconsistencies. The study concluded that besides the growth potential of the sector and its critical role in the manufacturing and value chains. There wide spread of the SMEs sector in Nigeria and the multiplier effects on the rest of the econo my enable them to be the engine of economic progress. Hassan and Olaniran (2011) examined how assistance institutions have contributed to the development of small and medium enterprises (SMEs) in Nigeria, with special reference to Industrial Development Centre (IDC), Osogbo, Nigeria. Survey research was used in order to carry out the study and three hundred and forty (340) respondents from university students, trade union congress and private entrepreneurs in Nigeria were sampled. Four research questions were generated from the literature review, questionnaire on developing small business entrepreneurs through assistance institutions, and the responses elicited from respondents were numerically quantified, tabulated and analyzed using the Likert Scale. The analysis of the study showed that assistance institutions in Nigeria, especially IDC, have really contributed immensely to the promotion of small and medium enterprises as well as entrepreneurship development generally. The study also examined some problems confronting SMEs in the developing nations like Nigeria. Based on the findings, the study recommended that efforts should be made to commercialize the products of IDC so as to meet the demand of the people. The study also recommended that special fund should be set aside to encourage entrepreneurs who may be financially handicapped after training on SMEs development.

Asikhia (2009) examined the attitude of the business owners to microfinance banks so as to uncover areas of necessary modification in the policy before it becomes moribund like SMEEIS. Primary data was employed by the study and analyzed using factor analysis, correlation, regression and simple percentage analysis. The study observed that every action of the business owners are gauged by the expectations conceived before commencement of banking relationship, it is these expectations and not the present relationship that determines their future decision. The study recommended that the effectiveness of microfinance banks business management skills as a development strategy is contingent in delivering both financial and business counseling to the operators. Adams (2007) postulated that industrialization of any sound foundation cannot be achieved without a properly developed SME industrial base. He further stressed that at any point in time in any nation's industrialization process, small and medium scale enterprises constitute as much as $75 \%$ of the industrial facility set-up and employing at least $60 \%$ of the total employment in the entire industrial environment. Dionco-Adetayo et al. (2006) assessed the enterprise promotion policy programs influencing the development of small scale industries. Specifically, the study aimed at identifying the programs for promoting small scale industries, appraising them in meeting the objectives, and examining the effects of these programs on business growth. The study was conducted in Lagos state where industries and commercial activities were highly concentrated. The dependent variable, development of small scale industries were measured according to manpower size, business structure, and technological development; while the independent variables, programs on enterprise promotion policy were operationalized and measured by statements using Likert scale method. The descriptive and inferential analyses of the data collected through questionnaire revealed that enterprise promotion programs were focused on fostering small scale industries in terms of technical, extension, training, technology adaptation and commercialization, and information services. The level of awareness of these various programs was low and therefore hindered small scale industries the opportunity to avail such services, thus affecting the enterprises' growth and development.

Ogujiuba, et al. (2004) examined credit availability to small and medium scale enterprises in Nigeria: importance of new capital base for banks - background and issues. The study adopted a conceptual analytical framework that employed theoretical and statistical comparative cross-sectional data to analyze the SMIEIS program in Nigeria vis-à-vis capital base of banks in ascertaining whether it offers an effective means of solving the problem of funding small and medium scale businesses in Nigeria and its attendant implication for financial stability in the system. The analysis of the study confirmed government need to urgently address the problem of financial intermediaries cum stability in the system as a national priority and build institutions that would drive the reform process. The study recommended that banks could play more active role in actualizing the objectives of SMIEIS by re-capitalizing and setting up separate desks to manage the fund and vigorously conversing the idea such as any other bank product. This will mitigate the problem of weak assetbased and heavy collaterals. The study also recommended that the macroeconomic environment should be 
stabilized through proper fiscal and monetary policy coordination to reduce interest rates, stabilize prices and reduce rent seeking behavior among economic agents. Sanusi (2003) posited that the role of small and medium-scale enterprises as a catalyst for economic growth and development has been well documented in the economic literature and recognized in most countries. The study stressed that in most of the newly industrialized nations; more than 95 percent of all industrial enterprises belong to the SME sector and that the sector accounted for bulk of the labor force. From the above, it was evident that lots of studies have examined the importance of SMEs in both developed, developing and the Nigerian economy in particular. This study adds to existing studies by analyzing the impact of banks loan to SME sector on manufacturing output in Nigeria between 1992 and 2010.

\section{Methodology}

Analytical Framework and Model Specification: To examine the contribution of banks loan to SME sector on manufacturing output, this study rest on the neoclassical production functions. The neoclassical aggregate production function exhibit constant returns to scale in labor and reproducible capital which is written in general form as:

$$
Y=F(K, L)
$$

Where $Y$ is output, $K$ is the stock of capital, and $L$ is the labor force. This function expresses the output $Y$ under a given state of knowledge, with a given range of available techniques and a given array of different capital, intermediate goods and consumption goods. With constant returns to scale, output per worker (i.e. labor productivity) $y \equiv Y / L$ will depend on the capital stock per worker (i.e. capital intensity) $k \equiv K / L$. Under the assumption of constant returns to scale, the relationship each unit of labor has with capital in production does not change with the quantity of capital or labor in the economy. A crucial property of the aggregate production function is that there are diminishing returns on the accumulation of capital. In other words, each additional unit of capital used by a worker produces a decreasing amount of output. A form called the CobbDouglas function usually expresses the relationship in equation (1) as:

$$
Y=L^{\alpha} K^{\beta}
$$

Introducing the variable $F^{\theta}$ which represents banks loan to SME sector into equation (2), real output (Y) is therefore a function of the capital stock, existing labor force and the level of bank loan to SME $\left(F^{\theta}\right)$ which is a policy variable. This shows that with the existing level of capital stock and labor force, it is possible to have an increase in the growth rate of real output through increased measures of bank loan to SME sector. This is because bank loan to SME sector allows for increased availability of financial resources, leading to changes in capital stock and labor force which is expected to result in increased output; therefore, equation (2) becomes:

$$
Y=L^{\alpha} K^{\beta} F^{\theta}
$$

From equation (3), the log-linear relationship between bank loan to SME and manufacturing output is expressed as:

$$
\ln Y=\alpha \ln L+\beta \ln K+\theta \ln F_{\text {。 }}
$$

Drawing from equation (4) and introducing a constant, an error term and the short term interest rate, the final estimating model for this study is expressed as:

$$
\operatorname{In} Y_{t}=\alpha_{0}+\alpha \operatorname{In} L_{t}+\beta \operatorname{In} K_{t}+\delta \operatorname{In} F_{t}^{\theta}+\gamma R_{t}+\varepsilon_{t}
$$

Equation (5) presents the long run relation between the variables. To estimate the short run relationship among the variables, the corresponding error correction equation is expressed as:

$$
\Delta \operatorname{In} Y_{t}=\alpha_{0}+\sum_{i=1}^{n} \lambda \Delta \operatorname{In} Y_{t-i}+\sum_{i=1}^{n} \alpha \Delta \operatorname{In} L_{t-i}+\sum_{i=1}^{n} \beta \Delta \operatorname{In} K_{t-i}+\sum_{i=1}^{n} \delta \Delta \operatorname{In} F_{t-i}^{\theta}+\sum_{i=1}^{n} \gamma \Delta R_{t-i}
$$




$$
+\psi E C T_{t-1}+\varepsilon_{t}
$$

Where:

The $E C T_{\mathrm{t}-1}$ is the error correction term of the short run equation

$Y$ is manufacturing output;

$K$ is capital stock;

$R$ is interest rate;
$L$ is labor force;

$F^{\theta}$ is the bank loan to SME;

$\alpha_{0}$ is the constant; and $\varepsilon_{t}$ is the error term.

Data Measurement and Sources: manufacturing output is measured by the output of the sector over the period of study; labor force is measured by the total working population; capital stock is proxy by gross capital formation; bank loan to SME sector is measured by the yearly amount of bank loan advanced to the sector; interest rate is measured by monetary policy rate (MPR). Data on manufacturing output (Y), gross capital formation $(\mathrm{K})$, bank loan to SME sector $\left(\mathrm{F}^{\theta}\right)$, and interest rate $(\mathrm{R})$ are obtained from the Central Bank of Nigeria (CBN) statistical bulletin while data of labor force is sourced from the World Bank Database. All variables with exception to interest rate are transformed into logarithms form.

\section{Results}

Unit Root Test: The Augmented Dickey-Fuller (ADF) test on the left hand of the table 1 revealed that the variables; manufacturing output (lman), gross capital formation (lgfcf), loan of SME sector (lsme) and interest rate (itr) are integrated of order one while labor force (llab) is integrated of order two that is the variable is an I(2) series. The findings of the ADF test is confirmed by the Phillip-Perron result on the other column (right hand) of table 1.

Table 1: Unit Root Test Results

\begin{tabular}{lllllll}
\multicolumn{2}{l}{ Augmented Dickey-Fuller (ADF) Test } & \multicolumn{4}{l}{ Phillip-Perron (PP) Test } \\
\hline Variables & Level & $1^{\text {st }} / 2^{\text {nd }}$ Diff & Status & Level & $1^{\text {st }} / 2^{\text {nd }}$ Diff & Status \\
lman & -2.6188 & $-3.2180^{* *}$ & $\mathrm{I}(1)$ & 1.6257 & $-3.1972^{* *}$ & $\mathrm{I}(1)$ \\
llab & -4.0277 & - & $\mathrm{I}(0)$ & -4.0277 & - & $\mathrm{I}(0)$ \\
lgfcf & -1.5779 & $-3.9857^{*}$ & $\mathrm{I}(1)$ & -1.6694 & $-3.9857^{*}$ & $\mathrm{I}(1)$ \\
lsme & -1.7764 & $-5.1303^{*}$ & $\mathrm{I}(1)$ & -1.2430 & $-5.0048^{*}$ & $\mathrm{I}(1)$ \\
itr & -1.9321 & $-7.8123^{*}$ & $\mathrm{I}(1)$ & -1.9321 & $-7.8123^{*}$ & $\mathrm{I}(1)$ \\
\hline
\end{tabular}

Note: ${ }^{*}=1 \%$ and ${ }^{* *}=5 \%$ significance level.

Co-integration Estimate: From the co-integration estimate on table 2 below, it is revealed that the null hypothesis of no co-integration, for $\mathrm{r}=0$ was rejected by the trace statistic and the maximum-eigen statistic. The statistic values of both the trace and maximum-eigen value statistic were greater than their critical values at $r=0$. However, the null hypothesis of no co-integration at $r \leq 1$ could not be rejected by both the trace statistics and the maximum eigen-value statistic because their statistic values were less than their critical values. Thus, the result showed one co-integration equation, which suggests the existence of a long run relationship among the variables employed.

Table 2: Summary of the Co-integration Estimates

\begin{tabular}{llllllllll}
\hline \multicolumn{2}{l}{ Trace Test } & \multicolumn{7}{c}{ Maximum Eigen value Test } \\
\hline Null & alternative & Statistics & $\begin{array}{l}95 \% \\
\text { values }\end{array}$ & critical & Null & alternative & Statistics & $\begin{array}{l}95 \% \\
\text { values }\end{array}$ & critical \\
$r=0$ & $r \geq 1$ & 90.455 & 47.856 & & $r=0$ & $r=1$ & 41.556 & 27.584 & \\
$r \leq 1$ & $r \geq 2$ & 48.900 & 52.237 & & $r \leq 1$ & $r=2$ & 20.663 & 21.316 & \\
$r \leq 2$ & $r \geq 3$ & 28.236 & 31.560 & $r \leq 2$ & $r=3$ & 17.349 & 18.652 & \\
$r=0$ & $r \geq 1$ & 10.887 & 13.068 & & $r=0$ & $r=1$ & 10.887 & 13.068 & \\
\hline
\end{tabular}


Long run Estimate: The result of the long run relationship among the variables is presented below.

lman $=-17.380+1.639 \mathrm{LLAB}_{\mathrm{t}}+0.030 \mathrm{LGFCF}_{\mathrm{t}}+0.004 \mathrm{LSME}_{\mathrm{t}}+0.009 \mathrm{ITR}_{\mathrm{t}}+\varepsilon_{\mathrm{t}}$

$$
\begin{array}{llll}
(0.000) * & (0.518) & (0.924) & (0.788)
\end{array}
$$

Note: values in parenthesis are p-values and *implies significant at one percent.

As observed from the long run equation, labor force has a positive and significant impact on manufacturing output. A one percent increase in labor force would result in an increase in manufacturing output by 1.64 percent. This finding indicates that increase in gainfully employed labor by the manufacturing sector would positively stimulate output growth of the sector. Other explanatory variables (lgfcf, lsme and itr) in the model were observed to have an insignificant effect on manufacturing output. Thus, with respect to the key variable (that is bank loan to the SME sector (LSME)), the positive relationship exhibited by its coefficient indicates that, an increase in banks loan to SMEs would enhance manufacturing output but the increase was insignificant. Thus, it can be concluded that bank loan to SME sector has no significant effect on manufacturing output in the long run.

Short run Estimate: Table 3 presents the parsimonious regression estimate capturing the short run analysis. From the table, it is observed that the model is fit and appropriate for the analysis. The adjusted R-squared of the model is 0.89 percent, suggesting that a high proportion of variations in manufacturing output were explained by the explanatory variables in the model. The high and significant value of the F-Statistics further confirmed the fitness of the model. The Durbin Watson Statistics in the model is 2.12, indicating that the model is free from the problem of serial auto-correlation. The coefficient of error correction term is statistically significant and negative. The negative sign of the error correction term indicates a backward movement toward long run equilibrium from short run disequilibrium. With regard to coefficients of the explanatory variables, it was observed that the first lagged values of manufacturing output and labor force had significant and positive effect on current manufacturing output. The first lagged value of interest on banks' loan to SME sector had a positive and insignificant effect on current manufacturing output, while the first lagged value of gross fixed capital formation had a negative and significant effect on current manufacturing output. An important implication of the above findings with respect to the variable of interest is that bank loan to SME sector has no significant influence on manufacturing output in Nigeria.

Table 3: Short run Estimate

\begin{tabular}{llll}
\hline Variables & Coefficient & T-Statistics & Probability \\
\hline C & 0.9059 & 5.2375 & 0.0000 \\
ECM $(-1)$ & -0.4410 & -4.5205 & 0.0009 \\
$\Delta$ LMAN $(-1)$ & 0.3941 & 3.8661 & 0.0026 \\
$\Delta$ LSME(-1) & 0.1709 & 0.6781 & 0.1318 \\
LLAB $(-1)$ & 0.4711 & 3.1689 & 0.0132 \\
$\Delta$ LGFCF(-1) & -0.0348 & -4.2386 & 0.0014 \\
Adjusted R-squared & 0.8883 & S.D Dependent Var. & 0.0467 \\
S.E of Regression & 0.0170 & F-Statistic & 26.4547 \\
Durbin-Watson Stat. & 2.12 & Prob (F-Statistic) & 0.0000 \\
\hline
\end{tabular}

\section{Conclusion and Recommendations}

The small and medium scale sector has been responsible for aiding growth and employment generation in countries like the United States and some Asian and emerging countries of the world. In view of this, this study examined the extent to which banks loan to the SME sector has impacted on manufacturing output in Nigeria for the period spanning 1992 to 2010. Based on the regression estimate, it was observed that the effect of bank loan to the SME sector on manufacturing output was insignificant both in the long and short run. This simply implied that the purpose and objective of this loan to stimulate output has not been successful. Based on the above, this study recommended the need for greater deliberation and conscious effort by the government to ensure that loans reach those in real need. There is also the need for moderation of collaterals and interest rate attached to such loans to make more attractive to stakeholders in the SMEs sectors. 
Area of Further Research: This study examined the relationship between banks loan to SMEs and manufacturing output in Nigeria and observed that the impact of banks loan to SMEs had an insignificant effect on manufacturing output. This study can be further enriched by directing examining the contribution of the Small and Medium Industries Equity Investment Scheme (SMIEIS) initiated in 2001 on the performance of the SMEs sector. Extending the study in this area would definitely enrich the policy recommendations of the government in enhancing the performance of the SME sector.

\section{References}

Adams, A. A. (2007). Promoting Medium and Small scale industries in Nigeria-The Partnership option between Government and private sector entrepreneurs. The Nigerian Banker-Journal of the Chartered Institute of Bankers of Nigeria, 4(2).

Aremu, M. A. \& Adeyemi, S. L. (2011). Small and medium scale enterprise as a survival strategy for employment generation in Nigeria. Journal of sustainable development, 4(1), $200-206$.

Asikhia, O. U. (2009). Attitudinal Response of Small and Medium Scale Business Owners to Microfinance Banking in Nigeria. European Journal of Social Sciences, 11(4).

Dionco-Adetayo, E. A., Awoniyi, M. O., Adetayo, J. O. \& Elumilade, D. O. (2006). Enterprise Promotion Policy on the Development of Small Scale Industries in Nigeria: An Assessment. Refereed Paper; SMEEntrepreneurship Global Conference 2006.

Hassan, M. A. \& Olaniran, S. O. (2011). Developing small business entrepreneur through assistance institutions: The role of industrial development center, Osogbo, Nigeria. International of Business and Management, 6(2), 213-226.

Ogujiuba, K. K., Ohuche, F. K. \& Adenuga, A. 0. (2004). Credit availability to small and medium scale enterprises in Nigeria: Importance of new capital base for banks - background and issues. AIAE working paper.

Ogunleye, A. G. (2004). Small and Medium Scale Enterprise as Foundation for Rapid Economic Development in Nigeria. Small and Medium Enterprise Development and SMIEIS: Effectiveness Implementation Strategies, 33-37.

Sanusi, J. O. (2003). Overview of Government's Efforts in the Development of SMEs and the Emergence of Small and Medium Industries Equity Investment Scheme (SMEIS). A Paper Presented at The National Summit on SMEIS Organized by the Bankers' Committee and Lagos Chambers of Commerce and Industry (LCCI), Lagos on $10^{\text {th }}$ June, 2003. 